International Journal of Child, Youth and Family Studies (2015) 6(4): 581-594

\title{
REVOLUTIONARY LOVE: CYC AND THE IMPORTANCE OF RECLAIMING OUR DESIRE
}

\author{
Kathleen S. G. Skott-Myhre and Hans A. Skott-Myhre
}

\begin{abstract}
As we enter the second decade of the $21^{\text {st }}$ century, the question of what we do and why we do it as CYC workers cannot be ethically separated from the lived suffering, social and cultural marginalization, and direct oppression of the young people with whom we engage. The fundamental question is whether we accede to the demands of an ever more indifferent and brutalizing system of abstract economic rule, or respond with new forms of value, ways of living and caring for one another. This article will propose a framework of revolutionary love in partial response to these questions. The article will present a theoretical framework for a politics of Child and Youth Care premised in the post-Marxist writings on love and capitalism in the work of Gille Deleuze, Felix Guattari, and Antonio Negri.
\end{abstract}

Keywords: capitalism, desire, child and youth care, Deleuze and Guattari, love

Kathleen S. G. Skott-Myhre, Psy.D. is an Assistant Professor in the College of Social Sciences Psychology department at the University of West Georgia, 1601 Maple Street, Carrollton Georgia, U.S.A., 30118.

Email: kskott@westga.edu

Hans Skott-Myhre, Ph.D. is an Associate Professor of Child and Youth Studies at Brock University, 500 Glenridge Avenue, St. Catharines, Ontario, Canada, L2S 3A1.

Email: hskottmy@brocku.ca 
International Journal of Child, Youth and Family Studies (2015) 6(4): 581-594

\section{The Question of Feelings and Sociality}

If the field of Child and Youth Care is centered on the development and nurturance of relationships, then it might well be argued that a defining aspect of our work must engage the realm of affect and emotion. Certainly, for those working on the line in the day-to-day interactions between young people and adults in the countless institutional and quasi-institutional settings where we encounter young people, there is no more disruptive or rewarding aspect to what we do than the expression of feelings. Indeed, the functional capacity of a given program or classroom is often centered on the management and manipulation of emotionally-driven interactions between all of the people involved, both young and older. Such a web of affect and emotion comprises a kind of dynamic ecology with all of the features of the more familiar biological environmental ecologies.

Felix Guattari (2005) makes this point, when he reminds us that our very survival depends not just on our ability to manage the biosphere in which we live, but also the delicate and complex ecologies of our socially constituted consciousness and interwoven affective connectivity. He argues that the three ecologies (social, environmental, and conscious) are deeply interdependent. Without a healthy biosphere, human life would be severely challenged at the very level of survival. However, human consciousness plays a powerful role in shaping the physical environment in which we live. The way that we deploy our thoughts and creative capacities determines what we produce and how we produce it. Our rationality and reason give us the possibility of assessing the impacts of our behaviors on the biosphere. To the degree that we are capable of seeing clearly and accurately the ways in which our creative activities positively or negatively impact the web of life, upon which we are dependent, we are able to flourish in concert with each other species.

Guattari (2005) argues that both the biosphere and forms of social consciousness can sustain similar kinds of ecological damage that can weaken both the physical biodiversity and resilience of our social capacities. He makes the case that just as the physical environment has suffered degradation, so has the world of thought and sociality.

In terms of the physical environment, the historical period that encompasses the development of industrial capitalism and the European colonial project has produced massive shifts in the environment that include the loss of significant degrees of biodiversity and an increase in the level of substances that are toxic to living organisms. The shift from industrial capitalism to the current mode of virtual global capital has been marked by an alarming escalation in levels of pollution, unsustainable increases in human populations, and resulting levels of consumption that have shifted weather patterns in ominous and troubling ways.

Guattari argues that these negative developments have been matched in the arenas of human sociality and our capacity for creative thought and consciousness. He asserts 
International Journal of Child, Youth and Family Studies (2015) 6(4): 581-594

that key modes of sociality such as solidarity, universes of fraternity, sociability, neighborhood, human warmth, and inventiveness might well be listed on the endangered species list of thought and praxis. We would argue, that these modes of sociality are key to the work we do with young people and that if they are threatened under the current mode of capitalist economy, then this becomes a political issue of significant importance to child and youth care theorists and practitioners.

\section{Desiring Production}

The question of affect is crucial here. It is through our mutual emotional connections and affiliations that we construct our relations. And it is through our affective encounter with the world that we form the capacity for thought and, through the combination of thought and feeling, our very ability to be creative and to produce our world together (Spinoza, 2000). This is what Deleuze and Guattari (1983) refer to as desiring production. In this sense, desire is not premised in lacking anything, as in the desire to acquire that which we don't have. Instead, desiring production is the desire to act, to create, and to produce. Such desire, Deleuze and Guattari (1983) argue, is the foundation of all forms of human creativity and hence all forms of human sociality. What is in crisis, then, in our human social ecologies, is the ability to freely engage our desire.

It is Marx (1978) who reminds us that capitalism appropriates not just our laboring bodies, but also our modes of thought and how we come to see the world. Althusser (1971) called this ideology and argues that what we come to think of as common sense is actually the world given to us by the dominant logic of our age. Pignarre and Stengers (2011) call the ability of capitalism to convince us that the logic of the dollar is the logic of life, a form of sorcery. They propose that capitalism's ability to appropriate the fabric of social and emotional production is premised in the ability to have us believe that the logic of capitalism is eternal. That is to say, that rampant individualism, selfishness, the money sign as the primary driver of society, and a radical disregard for future consequences, is intrinsic to human thought and behavior. Pignarre and Stengers suggest that capitalism would have us believe that capitalist logic is simply the way things have always been, will always be, and there is no real alternative to capitalism. Guattari (2005) refers to this as the logic of "ignorance and fatal passivity" (p. 34).

To counter such a logic, Pignarre and Stengers (2011) suggest that we need to develop a counter-sorcery, an alternative common sense, if you will. If capitalism holds us in a trance that denies any form of living except subjection to its logic and domination, then to break the trance, we must access an experience powerful enough to wake us up to the reality of our creative capacities. As Marx (1978) powerfully informs us, we must come to understand that we produce the world in our material and actual interactions.

To understand the contradiction here, it is important to remember that capitalism is a system of abstract signs, such as money, that doesn't produce anything substantive. As Negri (1996) tells us, to survive and expand, capitalism must appropriate our living creativity and transform it into the abstraction of money. This is a sleight of hand through 
International Journal of Child, Youth and Family Studies (2015) 6(4): 581-594

which capitalism convinces us that what we do is worth merely what can be measured in money. The trick can work only if we cooperate in the illusion. The magic trick can be seen for what it is and a new mode sociality engaged, only if we seize back our own desiring production.

\section{Capitalist Appropriation of our Social Lives}

We would argue that it is through fields of engagement, founded in human relationships, such as child and youth care, that desiring production can be engaged and put to work. To do this, it is important to challenge the ways in which the abstract system of capitalist value has inveigled itself into the very fabric of our social lives. In its most recent iteration, capitalism has gone beyond dominating and controlling our bodies so that we are willing to subject our physical creative capacities to the regimes of the factory. Under the current mode of production, it is our very ability to think and to interact that has become the object of capitalist subjectification. We have replaced the physical tedium of the factory for the mind numbing tedium of the call center. In this shift, capitalism has begun to appropriate our capacity for communicating, socializing, caring, and thinking together.

As Hardt and Negri (2009) have pointed out, this has infected our workplaces through the new technologies of social networking. In our own field, we can see an emphasis on the importance of teams working together smoothly and managing the affective, emotional components of our work together. Indeed, a child and youth care worker's evaluation may well include commentary on how well you interact with your teammates and how well you control your negative affects. You might need to take courses on anger management, either for yourself, or so you can manage the feelings of the youth with whom you work, or even your fellow team members. It has become important that you learn to be happier at work. To evidence satisfaction with your employment is now part of your responsibilities. It doesn't matter how well you work with young people and families, getting along with your teammates and management becomes a central task. Having good social skills and effectively communicating with others become central to your evaluation. It is important to note that many of the responsibilities of managing the affective relations of the workplace fall to women, as that group that has traditionally been responsible for these functions in the home. As they move from the home into the workplace, they are expected to transfer nurturance and caring from their family to their co-workers (Skott-Myhre, 2015).

Of course, one might argue that good social skills, communication, and teamwork are essential elements of good child and youth care work. However, it is not the skill sets themselves that are at issue. It is their appropriation to the ends of the system of value that is capitalism. To be a good team player means to avoid friction, disruption, disobedience, and resistance to command. To effectively communicate means to seamlessly disseminate the messages and instructions of the institution. To care for others means to make sure that they are happy, which translates into compliance with the corporate dictates of what looks like emotional satisfaction. One should demonstrate how pleased one is to work here. Our teams must care for each other in such a way that we all 
International Journal of Child, Youth and Family Studies (2015) 6(4): 581-594

are working as one joyful productive unit. It is, as Hardt and Negri (2009) put it, a corruption of our social and emotional capacities, or as Guattari would have it, a degradation of our social, emotional, and intellectual ecologies.

To the degree that the above-mentioned corruption and degradation have infiltrated our work, it turns our intended goal of deploying relationship as a life affirming force into a copy that turns on itself. In this turning, our desiring production, as emotions, thoughts and sociality, becomes frustrated and blocked. This blockage can cause an overwhelming sense of frustration, futility, and impotence. Our very ability to care for one another is turned into a pale shadow of its truly revolutionary potential and is diverted to the needs of the abstract addiction that is capitalism. Is it any wonder that under such circumstances, we experience epidemic levels of burnout, anxiety, and depression (Smullens, 2012) or that we turn away from our central work of creating productive social relations with the young people we encounter and instead put our energies into becoming “professionals”?

The obstacles to our desiring production close off our access to affect based in actual material relations. Instead of being able to come together to discuss the ways that our workplace impinges on our freedom to work with young people and each other in socially relevant ways, we are left with a severely diminished set of possible conversations about discipline, control, trauma, diagnosis, and so on (see Mattingly, Stuart, \& VanderVen, 2010). If we do discuss our emotions, it is within the framework of our own separate and individual struggles. Seldom do we have a conversation as a "team" about the common experiences we share of anxiety, depression, and impotence. If we do, such conversations tend to center around our own individual limitations, traumatic histories, or lack of social/emotional competence. Indeed, most of the conversations about emotions are decidedly managerial. We discuss how we might manage our feelings in the workplace rather than what social and material conditions might be at the root of our discomfiture (Hardt \& Negri,2009; Koeske \& Koeske 1989).

Feelings such as love, solidarity, and affectionate caring for young people are often carried on as if they were an aside and not the primary impetus of our work. If we engage with powerful feelings such as love, we are frequently dismissed as overly sentimental or not seriously engaged in the clinical practice of behavioral change. In fact, robust positive affects such as love are mostly discussed in the framework of a problem, such as a transgression of what is considered to be a professional boundary or as a dangerous engagement between co-workers who are erotically or romantically involved. Of course, there is always the issue of an erotic or emotional relationship, or a fantasized relationship between a young person and a worker. In short, conversations about powerful emotions such as love are held within the framework of threats to the institution or as a disciplinary issue. Here again, our emotional capacities, even those with a positive valence, are regulated and controlled by institutional and professional parameters, rather than constituted by the actual relations between those doing the work. 
International Journal of Child, Youth and Family Studies (2015) 6(4): 581-594

\section{Self-Care and Boundaries}

The institutional management of powerful emotions in our work is relegated to the questions of self-care and boundaries. We are warned not to let our feelings have too much impact in the workplace. Love, but not too much. Care, but with boundaries. Protect yourself from your engagement with other living humans because they can compromise your professional positioning and your smooth functioning as a good worker. Be sure to remain in full control of your feelings at all times. If you need help with this, the institution will provide workshops, trainings and even outside help to assist you in using your capacity for relationship to the benefit of the institution.

The training we receive, both culturally and professionally, in the paradigm of the psychological individual supports these institutional frameworks. The idea that our emotions reside within us and are our responsibility, promotes the belief that we must be in control. If we experience negative or dystonic affects, it is because of some lack on our part. If we are anxious, worried, or depressed, it is because we have not learned to manage the traumas and vicissitudes of life, or perhaps we are suffering from a biological or chemical imbalance. The solution to such dilemmas is either to learn to manage our feelings through the application of reason and rationality, or to seek to have our biochemistry altered by the pharmaceutical/medical industry. In this, there is no opportunity to discuss the pervasive commonality of these affects. The fact that most of us are experiencing these dystonic affects and that maybe such affects are not simply the effect of a dysfunctional individual psychology or biology is hidden from view and excluded from discussion.

If we could talk about our experiences together, we might discover that such feelings could be a response to a dysfunctional social system as we have suggested above. If we were to have these discussions, then we might well think about our programs not as amalgams of individual psychopathology shared to varying degrees by young people and adults, but as collectivities premised in what we hold in common. We might consider our programs from the perspective of an emotional milieu where feelings happen between people, not within people. In this, our discussions might center on how we as a group could set and produce the emotional temperature of our program. The focus would move from the management of individual emotions, to exploration of how our common experiences might inform our understandings of what is happening to us collectively within the institutions where we work. The emotional temperature of a program would be understood as responsive to an ever shifting, complex, and specific mix of personal history, social hierarchies, physical environmental constraints, and institutional norms and behavioral expectations. In short, our programs would become premised in the practical application of the idea that we think and we feel, and we act collectively. 
International Journal of Child, Youth and Family Studies (2015) 6(4): 581-594

\section{Accessing Our Desire}

We argue, that the vehicle for making this kind of shift lies in our ability to access our desire. This kind of desire, as noted above, is not premised in any kind of lack. Indeed, Deleuze and Guattari (1983) point out that lack is the driving engine of capitalist rule. It is through the idea that something is always missing from our lives, that we are deficient in some way, and that capitalism can create us as subjects who consume. Deleuze (1992) makes this case when he argues that under global capital, we are controlled by our credit reports. Our credit reports are, of course, based on the degree to which we successfully manage debt. Under the current system, we are encouraged from all sides to expend more than we have for things that are sold to us, as though they were the answer to our dystonic sense of alienation and impotence. Such a social system is premised on an ongoing perception that there is never enough, but if we keep accumulating, someday we will win the lottery and be secure and in command of our destiny. Deleuze calls this a system of infinite deferral in which our goals are always deferred and unattainable. For example, no degree, diploma, or training program will assure us secure ongoing employment. As soon as we become certified professionals, the requirements change or the job category literally disappears.

This set of contradictions and antagonisms functions through the logic of what Deleuze and Guattari (1983) term the paranoid pole of production. This mode of production restricts social capacities and movements by overdetermining them according to pre-set patterns of meaning. Such meaning is not derived from the actual lived experience of life rather through "an absolute system of belief...permanently fixed and exhaustively defined by a supreme authority, figure-head, or god” (Holland, 1999, p. 3). Such authority operates from outside the material realm and derives its absolute rule from its universal coding of living force. Capitalism over-codes the rich and infinitely variable flows of life into the singular form of the money sign. Since the money sign is both an arbitrary and abstract form absolutely separate from life, when the value of living things is measured according to money they will invariably come up short. In other words, there will always be a sense of lack driving human beings to try to attain more of an ever shifting and abstract sign that is ultimately alien to their interests.

We can see this capitalist over-coding in the work we do when a program puts "financial survival" as measured in grant dollars and funding over the actual needs of living staff and children. Indeed, this is the discourse that tells us that there is not enough money for schools, medical care, decent housing, and the like, yet there is more than enough money for wars, mansions, and yachts. It is the language of austerity in which the well-being of stock markets and national economies are given more importance than the subsistence needs of living species, human and other. This story of lack, where there is never enough, frames our desires as inevitably frustrated by definition.

The alternative definition of desire is derived from within the lived experience of the actual material realm. It is founded in the living force of life itself, which is infinitely creative and always collective. There is nothing abstract about it. It operates through production from the smallest atomic particle to the largest cosmic configuration of 
International Journal of Child, Youth and Family Studies (2015) 6(4): 581-594

galaxies and dark matter. It operates, as Guattari has suggested, continuously as a series of interwoven ecologies. In this sense, our human desires are never built upon abstraction, but out of our literal idiosyncratic capacities as singular bodies in combination with other bodies to produce webs of actions and thoughts. Deleuze and Guattari (1983) tell us that we never speak, write, think, or act in isolation. All of our thoughts and actions are premised in relationship. This is the source of our desire as the collective force to act and produce. Deleuze and Guattari propose that we are all working together all the time. Each of us in our own productions is composed of all the people and elements we have and will encounter. We lack nothing because we have all of the force of the cosmos available to us. We are a crowd.

\section{Who Is Our Crowd?}

The idea of life force, of course, takes us back to the question of relationship in child and youth care. Who is our crowd? It is simply all of us. It is everyone we encounter during our work together. This is the reason that it is so important to the systems of domination to keep us isolated, fearful of each other, and insecure about our capacities for production. If we actually accessed our crowd from within the work we do, child and youth care would become a powerful set of activities indeed.

However, it is not simply the youth and adults we encounter physically in our day-to-day work. Although we may be separated by geography, time, and differences in culture and social practices, in a globalized world, we now all operate as a kind of community. With access to the Internet and increased flows of human beings and other species across, what can only be called, the mythical borders of the nation state, the idea that any of us operates in isolation is patently ridiculous (Hardt \& Negri, 2009). Indeed, whether we know it or not we are involved, quite literally, in the three ecologies of environment, thought, and consciousness that Guattari described. Our modes of desiring production are constantly bringing the future into being. This is happening at the level of a child and youth care program within its own physical parameters, and it is also happening in all the global interactions on the Internet and other social media that staff and young people access daily. The question is: What future is to be called forth? Which form of desire will define who we are to become?

It is to this end that the force of life and desire, as played out in the relational work in child and youth care, becomes forcefully political. And it is here that the question of desire as affective force can be re-engaged. If, as we noted above, relationships are driven and produced through affective and emotional resonance, then desire as productive force flows along trajectories of feeling. Perhaps, in our work, one of the most powerful passionate resonances not driven by lack is what we might call political love.

Given our description of the mechanisms of capitalist domination and emancipation through our desiring production as a collective project, we might well define political love as the creation of new forms of community that serve the common desire of us all. If this were the case, then our relational task as child as youth care workers would shift from the registers of lack and control towards experimentation with 
International Journal of Child, Youth and Family Studies (2015) 6(4): 581-594

the force of living desire. In other words, we would shift our work away from attempting to manage and control young people and, instead, work with them on developing new ways to perceive the world and our place in it. Through this, we might explore alternative methods for developing joint capacities for creativity. As social and cultural innovators, we could possibly seek out new configurations of identity premised in our fresh encounters with our "crowd”.

\section{Abandoning Lack}

To search for this new identity, we would need to abandon lack in all its variations and codes. The regimes of traditional psychology, psychoanalysis, and psychiatry with their focus on dysfunction, diagnosis, and developmental over-coding would be abandoned in favor of models of desire and the unconscious premised in the richness of our collective force working together for a common purpose. As Guattari (2010) points out, perhaps we have the unconscious we deserve already pre-structured and over-coded with the language of lack and deficit. Alternate models of unconscious desire rooted in the earliest pre-structural writings of Freud (1997), the schizoanalytic writings of Deleuze and Guattari (1983), or the work of the psychiatric hypnotist Milton Erickson (Erickson \& Rossi, 1980) might form a new framework for how we could move away from ourselves and our subjectivity. In these writings, we might be able to find a way to think about our relationship with young people and each other, premised in the ways we could connect collectively through our common experiences and modes of creative expression (Krueger, 2005). We could explore the contingent production of our mutual modes of who we are constantly becoming rather than engaging in the archeological exercises of exploring the trauma of who we have been. Such an investigation would not be framed by pre-existing frameworks developed by disciplinary experts, but premised in material and contemporary tangible sets of relations not transcendent abstraction. This would require that we abandon the intoxicating effects of abstract codes and idealist aspirations in favor of the sobriety of actual encounter.

Hardt and Negri (2009) tell us that this kind of work is the fundamental political task. To develop new modes of subjectivity and consciousness as the primary driving impetus for our work reconfigures the field of child and youth work away from complicity with the dominant system of rule and towards what Hardt and Negri (2009) propose as love as revolt.

\section{Love}

Hardt and Negri (2009) tell us that love, in this sense, is not love as traditionally imagined within the dominant sphere of social coding that is capitalism. Such love is neither passive nor spontaneous. This love is not bounded by the binary world of the couple, the stifling confines of the family, or the paranoid configurations of the nation, the people, or the community. Indeed, Hardt and Negri propose that we seek to love those most alien to us first, in order to expand the field of love as far as we can. This is love of the crowd as those closest and those furthest away. Implied here, is the idea that love does not simply happen to us, as if it were an event that mystically arrives from 
International Journal of Child, Youth and Family Studies (2015) 6(4): 581-594

elsewhere. We must actively love in the same way we actively create our lives and ourselves together from all the elements available. In this sense, love operates as a connective flow between Guattari's (2005) ecologies. Love is that which connects thoughts, consciousness, and the physical environment in each moment. Love is "an action, a biopolitical event, planned and realized in common” (Hardt \& Negri, 2009, p. 180). To love in this way is not simple. It requires thoughtful reflection and bold experimentation. To attempt our work as the kind of love that revolts against the strictures and dominant codes of our profession and discipline is both dangerous and, we would argue, necessary. While some might reason that this kind of political work is outside the scope of child and youth care, we would maintain that, as a relationally derived field ostensibly dedicated to the well-being of young people, it should be its central function.

We contend that the stakes are high. If we are to ethically engage in the care of young people, then it is hypocrisy of the highest order to suggest that life as it is lived today under global capitalism is something to which young people should accommodate. There is no caring for anyone, much less young people, under the current system of value. If we are to take seriously our mandate of care, then a new mode of life that is attentive to the needs of actual living beings and a celebration of their capacities needs to be explored, and an alternative system of value implemented. The idea that things can go on for human beings without serious negative repercussions is fast becoming an obvious delusion. If we love the young people that we encounter in our work and ourselves, then we must open the field of child and youth care to actual fields of struggles and sets of relations.

While this sounds like a daunting and somewhat ominous task, with potential career ending possibilities for any child and youth care worker reckless enough to attempt it, there are both comfort and revolutionary force in accessing our crowd. It is in discovering and experimenting with those in our crowd that we might become fearless through the force of love. By seeking out those young people and fellow workers who are searching for alternate ways of thinking and being, we begin to create something else. This is, after all, how child and youth care and youth work came into being in the first place. While we may venerate the founders of the field now as established and recognized elders, they were deviants and rebels. We would suggest that the roots of any true field of relational work are always driven forward by those with nothing left to lose; those who are so profoundly dissatisfied with how human beings are being treated that they are driven to find new ways to work. In our drive to become respectable, we have lost some of this spirit over the past decades. We are calling for its return.

\section{Revolt}

The force of such revolt, however, is not to be found in the single radical leader any longer. We must now seek our collective force together through the power and resilience of all living things. It is not enough to mount a radical platform and a set of brand-new slogans. Our time calls for social experimentation in new modes of life. We must find ways to break the hold of capitalist coding on our ability to think. Our 
International Journal of Child, Youth and Family Studies (2015) 6(4): 581-594

consciousness is saturated with the structures and old congealed forms of thought and perception. These outmoded perceptions need to be broken and ruptured to open new modes of perception. There are groups of young people across the planet experimenting in precisely these ways. One need only think about the involvement of young people in the community gardening movement, the anti-globalization demonstrations, Occupy, the recent global response to the shooting of young black men in the United States, the students who are putting their lives on the line in Mexico and Hong Kong, the youth work protests in the United Kingdom over cuts in services to young people, young people's involvement in Idle No More and the Aboriginal fight for sovereignty, as well as groups such as Femen and Pussy Riot among many others.

Our field needs to be in touch with these movements and with these experiments, rather than seeking the solace of old age in the bourgeois senescence of professionalism. It is also time to rethink our relations with other bodies and species. We can no longer imagine that care for young people can be restricted to their bodies and minds alone. It is a travesty to call what we do care, when we thoughtlessly allow the young people we care for to be subjected to the worst kinds of environmental pollutants, psychical, emotional, and physical. To say we care and then do nothing about the loss of biodiversity that will severely impact on the health and well-being of the next generation is irresponsible in the extreme. It is time to acknowledge that the web of living ecologies has grown to include humans, non-humans, and post-humans. The world of virtual technology can no longer be ignored. The three ecologies that Guattari argues need to be integrated cannot hold humans at the center. Our field needs to be rethought within the realities of the 21st century with all of its political and revolutionary imperatives.

We contend it is love as revolt that allows for the maximum exploration and expression of these imperatives. If we are to care for young people in the way that we have just described, then we need to investigate not what love is, but what it can do. If love is the connective force through which we find our maximum capacity for mutual and singular productive creativity, then it is through all of our relations that the new world can emerge. This love is not particular to our individual experience, but is related to who we are not yet. Love as care between us allows for the opening of experimental spaces where we can become more than what the dominant system tells us we are. Explorations of multiple forms of identity and configurations of our desires become the order of the day for our work together. If there is no lack, then we are free to open ourselves generously without restraint. We can give of ourselves in full expenditure without the anxiety and fear of running out of ourselves. Since we are not restricted as a particular subject but related concretely to all of creation, we can freely explore that which we hold in common. Hardt and Negri (2009) tell us that what we have in common is everything. However, we don't own it and it doesn't own us. Instead, it composes us and we compose it. These collective interests drive love as a connective force as they manifest in radical idiosyncratic difference in each moment and through the thoughts and acts of each body. In this, love is creative force manifested as radical difference.

It is our desire, our love, and our alterity that creates the world. It is important to remember that systems of domination only take over what life has created. If we are to 
International Journal of Child, Youth and Family Studies (2015) 6(4): 581-594

care for young people, it is imperative that we work to retake the force of our desire and the ability to create the world as an affirmation of living force. After all, perhaps love and desire connect the inherent force of life with the idiosyncratic capacities of each of us. If our field of child and youth care were to take the world of affective connectivity seriously, then we could access the possibility of living life as it is without mediation, subordination, or domination. Through seizing our desires as our own field of exploration and experimentation, we might be able to break down the barriers of exclusion, discipline, codes of loyalty, and cultural or social affiliation that separate and divide us. This could open our work as a site of mutual transformation where we can confront the struggles, contradictions, and antagonisms that form our current lived reality under capitalist rule. Some might claim that this is too idealistic, but we are not proposing, in the end, a particular form of society. What we are suggesting is that we open our relations to the kind of experimentation that both challenges current modes of subjugation and leads to new worlds and new people. This is already happening across the planet in a proliferation of minor revolt. The question becomes: What is the role of child and youth care in the emerging world of the 21st century? Will we be scrambling to please the regimes of dominance and control and calling it care, or will we be courageous enough to open new pathways that affirm the possibilities for living ecologies of care? It is an open question, yet one that will be answered by who we choose to become together. 
International Journal of Child, Youth and Family Studies (2015) 6(4): 581-594

\section{References}

Althusser, L. (1971). Ideology and ideological state apparatuses (notes towards an investigation). In Lenin and philosophy and other essays (pp. 127-220; B. Brewster, Trans.). New York and London: Monthly Review Press.

Deleuze, G. (1992, Winter). Postscript on the societies of control. October, 59, 3-7.

Deleuze, G., \& Guattari, F. (1983). Anti-Oedipus (R. Hurley, M. Seem, \& H. R. Lane, Trans.). New York: Viking.

Erickson, M. H., and E. L. Rossi. (1980). The collected papers of Milton H. Erickson on hypnosis. New York \& Toronto: Irvington; distributed by Halsted Press.

Freud, S. (1997). General psychological theory: Papers on metapsychology. New York: Simon and Schuster.

Guattari, F. (2005). The three ecologies. London: Bloomsbury Publishing.

Guattari, F. (2010). The machinic unconscious: Essays in schizoanalysis (T. Adkins, Trans.). New York: Semiotext(e).

Hardt, M., \& Negri, A. (2009). Commonwealth. Harvard University Press.

Holland E. W. (1999). Deleuze and Guattari's Anti-Oedipus: Introduction to schizoanalysis. New York: Routledge/Psychology Press. http://dx.doi.org/10.4324/9780203007426

Koeske, G. F., \& Koeske, R. D. (1989). Workload and burnout: Can social support and perceived accomplishment help? Social Work, 34(3), 243-248.

Krueger, M. (2005). Four themes in youth work practice. Journal of Community Psychology, 33(1), 21-29. http://dx.doi.org/10.1002/jcop.20033

Marx, K. (1972). The Marx-Engels reader (Vol. 4). New York: Norton.

Mattingly, M. A., Stuart, C., \& VanderVen, K. (2010). Competencies for professional child and youth work practitioners. Retrieved from http://acycp.org/images/pdfs/2010_Competencies_for_Professional_CYW_Practit ioners.pdf

Negri, A. (1996). Twenty theses on Marx: Interpretation of the class situation today. In Marxism beyond Marxism (pp. 149-180). New York: Routledge. http://dx.doi.org/10.4324/9780203610725

Pignarre, P., \& Stengers, I. (2011). Capitalist sorcery: Breaking the spell. New York: Palgrave Macmillan. 
International Journal of Child, Youth and Family Studies (2015) 6(4): 581-594

Skott-Myhre, K. S. G. (2015). The feminization of labour and the DSM-5. Annual Review of Critical Psychology.

Smullens, S. (2012, Fall). What I wish I had known: Burnout and self-care in our social work profession. The New Social Worker, Social Work E-news, 143. (Online magazine).

Spinoza, B. (2000). Ethics. (G. H. R. Parkinson, Ed. and Trans.). Oxford: Oxford University Press. 